VARIABEL

e-ISSN: 2593-302X dan p-ISSN: 2599-3038

This work is licensed under

a Creative Commons Attribution-NonCommercial 4.0 International License.

\title{
Evaluation of Fiber Content Based on Palm Plantation which Has Fermentation with Probiotic MOIYL
}

\author{
Yunilas $^{1}$, Lili Warly ${ }^{2}$, Yetty Marlida ${ }^{2}$, Irsan Riyanto ${ }^{2}$ \\ Faculty of agriculture, University of Sumatera Utara, Medan, Indonesia ${ }^{1}$ \\ Faculty of Animal Husbandry, Andalas University, Padang, Indonesia ${ }^{2}$ \\ yunilas11@yahoo.co.id ${ }^{1}$
}

\begin{tabular}{ll}
\hline \hline Keywords : & ABSTRACT \\
Probiotics MOIYL, NDF, & Probiotic MOIYL is a probiotic that contains \\
ADF, lignin & lignocellulolytic microorganisms derived from palm oil \\
& waste consist of Bacillus Sp YLB1, Trichoderma sp YLF8 \\
& and Saccharomyces sp YLY3 which are potential in \\
& degrading fibers. This study aims to determine the effect of \\
& MOIYL probiotic use of palm oil waste based on fiber \\
& fraction content (NDF, ADF and lignin). This research is \\
using Completely Randomized Design (RAL) factorial \\
pattern 3 x 4 treatment with 3 replications. Factor I \\
(various levels of palm oil waste substrate) and Factor II \\
lcombination of mixed inoculum or cocktail inoculum \\
indigenous microorganisms). Parameters observed \\
included neutral detergent fiber (NDF), acid detergent \\
fiber (ADF) and lignin. The results showed that the use of \\
MOIYL probiotic in fermentation had a very significant \\
effect (P <0.01) decrease NDF, ADF and lignin waste \\
palm plantation. Probiotic MOIYL-based waste oil plays a \\
role in degrading fiber (NDF, ADF and lignin) and can be \\
used as a source of fermentation inoculum.
\end{tabular}

\section{INTRODUCTION}

Plantation waste and palm oil plantations such as palm fronds and leaves, palm sludge and palm kernel cake (BIS) are potential sources of alternative feed ingredients as they are available throughout the year in sufficient quantities. Increasing the number of palm fronds, BIS and oil palm sludge produced by oil palm plantations and industry each year provides an opportunity to be used as a feed source of energy for ruminants.

Although palm bleach, BIS and palm sludge can be used as energy source feed but have limiting factors such as high fiber neutral detergent fiber (NDF), ADF and Llignin. High fiber content causes low digestibility of the feed. Besides lignin is an anti-nutrient for livestock, in addition to disturb digestion can also reduce the nutritional value of feed ingredients.

Provision of low quality feed with high fiber content, will produce a low digestibility, so to improve digestibility required a processing technology before it is given to livestock. One of the feeding 
technology that can be done is through fermentation biotechnology. Feed processing in biotechnology fermentation can involve local microbials both indigenous and endogenous microorganisms in order to overcome the problem of low quality of feed and its digestibility (Yunilas, 2016).

MOIYL is a palm oil-based lignocellulolytic microorganism containing Bacillus sp YLB1, Trichoderma sp YLF8 and Saccharomyces sp YLY3. The results showed that Bacillus sp YLB1 has a high ability in degrading fibers compared to other bacterial isolates. MOIYL plays a role as a cellulosome (multi enzyme complex) producing cellulase, silanase, mananase and lignoperoxidase enzymes, so MOIYL as a cocktail inoculum can be applied to high-fiber feed, especially waste plantation and palm oil industry (Yunilas et al., 2013).

The fermentation process involves microorganisms in degrading crude fiber, reducing lignin levels and anti-nutrient compounds so that the digestibility value of feed from waste can increase. The results of Ramin et al. (2010) showed that BIS fermentation using Aspergillus niger inoculum and Rhizopus oryzae was able to increase crude protein (PK) and reduce neutral detergent fiber (NDF) and acid detergent fiber (ADF) instead of using Trichoderma harzianum inoculum. Complete fermentation using mixed inoculum (cocktail inoculum) can increase protein content and decrease the fiber content of palm based fodder (Yunilas et al., 2014).

This study aims to determine the effect of MOIYL probiotic use of palm oil waste based on fiber fraction content (NDF, ADF and lignin). Based on the above, it is necessary to evaluate the effect of fermentation of palm oil waste with MOIYL probiotics to fiber fraction content (NDF, ADF and lignin).

\section{METHOD}

\section{Materials and tools}

The materials used include palm fronds and leaves, palm sludge, palm kernel oil (BIS), MOIYL indigenous microbial inoculum consisting of Bacillus sp YLB1, Trichoderma sp YLF8 and Saccharomyces sp YLY3, urea, mineral Brook et al $\left(\mathrm{MgSO}_{4} .7 \mathrm{H}_{2} \mathrm{O} ; \mathrm{FeSO}_{4} .7 \mathrm{H}_{2} \mathrm{O} ; \mathrm{MnSO}_{4}\right.$; $\mathrm{ZnSO}_{4} \cdot 7 \mathrm{H}_{2} \mathrm{O} ; \mathrm{K}_{2} \mathrm{HPO}_{4}$; thiamin hydrochloride), aquades, urea, chemicals for van soest analysis.

The tools used in this study include: autoclave, incubator, rack for fermentation, erlenmeyer, test tube, pipette, bunsen, measuring cup, digital scales, mask, gloves, sprayer, strap, plastic bag, knife, label, stationery.

\section{Research Methods}

The method used in this research is experimental method using Completely Random Design (RAL) factorial pattern $3 \times 4$ treatment with 3 replications.

Factor I: combination of substrate level of oil palm leaf midrib, BIS, palm sludge

$\mathrm{S} 1=80 \%$ palm leaf midrib $+10 \%$ oil palm $+10 \%$ bus

$\mathrm{S} 2=60 \%$ palm leaf midlives $+20 \%$ oil palm $+20 \%$ bis

$\mathrm{S} 3=40 \%$ palm leaf midrib $+30 \%$ oil palm $+30 \%$ bis

Factor II:mixed inoculum (cocktail inoculum) indigenous microorganism YL

M1 = Bacillus sp YLB1 + Trichoderma sp YLF8

M2 = Bacillus sp YLB1 + Saccharomyces sp YLY3

M3 = Trichoderma sp YLF8 + Saccharomyces sp YLY3

M4 = Bacillus sp YLB1 + Trichoderma sp YLF8 + Saccharomyces sp YLY3

\section{Research procedure}

\section{Preparation of mixed inoculum}

Rejuvenation of indigenous microbial isolates (bacteria, fungi and yeast) on the solid medium of each NA, PDA, and MEA, then incubated for 24 hours (bacteria), 72 hours (yeast) and 168 hours (fungi). 
The rejuvenation results are mixed according to the treatment. Preparation of liquid medium consisting of aquades, brook mineral $1 \%$, urea $0,5 \%$, molasses $0,5 \%$, and bran $2 \%$, then sterilized (autoclave). Indigenous microbial isolates of $1 \%$ were inoculated in aqueous medium, then incubated while shaken with shaker at $150 \mathrm{rpm}$ for 7 days (mixed inoculum) (Yunilas, 2016).

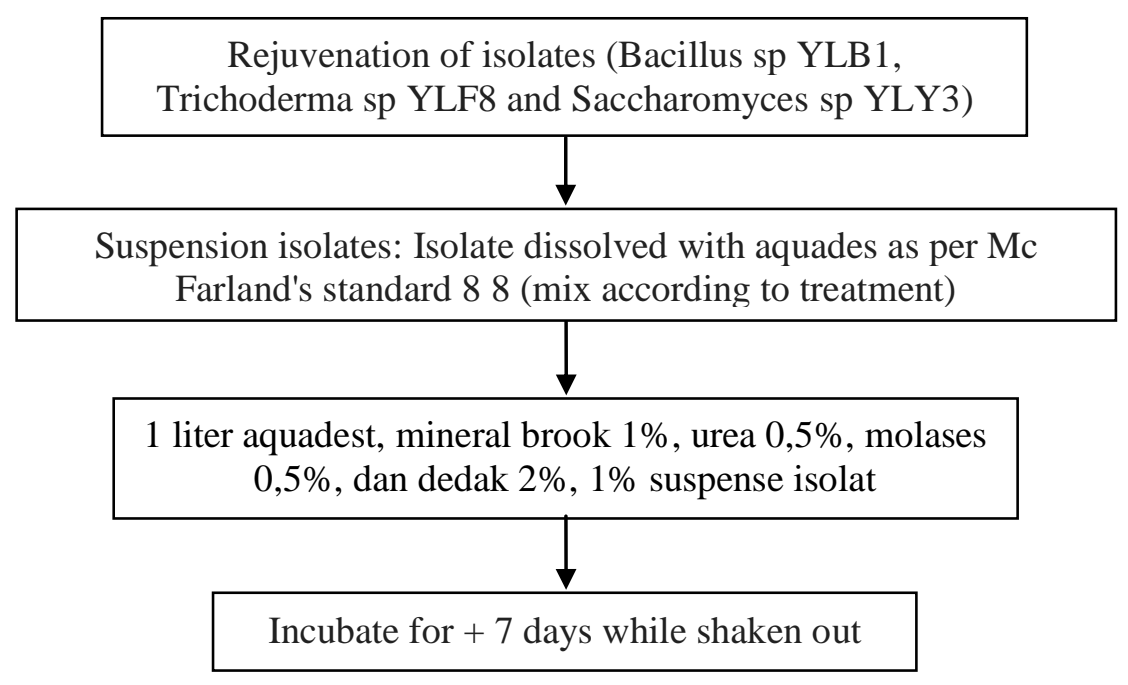

Fig 1. Inoculum Flow Chart Mix (cocktail inokulum) (Yunilas, 2016)

\section{Solid media fermentation}

The material (substrate) is weighed according to the treatment and then fed into the ester and sterilized using an autoclave at $121^{\circ} \mathrm{C}$ for 15 minutes. The substrate was cooled, after cold was inoculated with $1 \%$ cocktail inoculum, then incubated for 7 days.

\section{Measured Variables}

The variables measured were fiber analysis including NDF and ADF (Goering and Van Soest, 1973).

Determination of Neutral Detergent Fiber (NDF)

1. The sample was weighed as much as 1 gram (A) and then put into a test tube and $100 \mathrm{ml}$ of

NDS solution was added, 0.5 grams of sodium sulfite $\left(\mathrm{Na}_{2} \mathrm{SO}_{3}\right)$.

2. The solution is heated for 10 minutes to boiling.

3. After boiling, the solution continues to be heated for 60 minutes with occasional stirring.

4. The solution is then filtered using a known filter plate (glass filter No. GF-4) (B) and connected to a vacuum pump

5. Residue rinsed with hot water twice

6 . The residue is rinsed with acetone and silenced for a moment to remove residual acetone

7. The filter glass and its contents are heated in an oven at $105^{\circ} \mathrm{C}$ for 8 hours

8. Cool in desiccator then weighed (C)

Calculation:

$\mathrm{NDF}=\frac{\mathrm{C}-\mathrm{B}}{\mathrm{A}} \times 100 \%$

A

Information :

$\mathrm{A}=$ sample weight (gram)

$\mathrm{B}=$ weight of filter paper (gram)

$\mathrm{C}=$ weight of plate + sample after temperature of $105^{\circ} \mathrm{C}$ for 8 hours (gram)

\section{Acid Detergent Fiber (ADF)}

1. The sample was weighed as much as 1 gram (A) then put into the test tube and $100 \mathrm{ml}$ of ADS solution was added.

2. The solution is heated for 10 minutes to boiling. 
3. After boiling, the solution continues to be heated for 60 minutes with occasional stirring.

4. The solution is then filtered by using No. filter glass. The GF-4 is known by weight (B) and is associated with a vacuum pump

5. Residue rinsed with hot water twice

6. The residue is rinsed with acetone and silenced for a moment to remove residual acetone

7. The filter glass and its contents are heated in an oven at $105^{\circ} \mathrm{C}$ for 8 hours

8. Cool in desiccator then weighed (C)

Calculation:

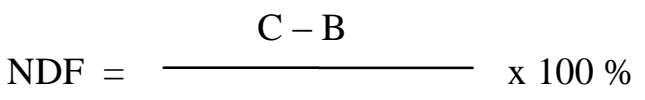

\section{A}

Information :

A = sample weight (gram)

$\mathrm{B}=$ weight of filter paper (gram)

$\mathrm{C}=$ weight of plate + sample after temperature of $105^{\circ} \mathrm{C}$ for 8 hours (gram)

Statistic Analysis

Statistical analysis of this study using analysis of variance (ANOVA). The design used was a complete randomized design (RAL) factorial pattern. If there is a treatment effect proceed with Duncan multiple range test (Steel \& Torrie, 1995).

\section{RESULTS AND DISCUSSIONS}

Fermentation biotechnology using MOIYL based on plantation waste and palm oil industry at various substrate level combination treatments showed significant results on the content of neutral detergent fiber (NDF) and acid detergent fiber (ADF). The effect of complete fermentation of plant based waste and palm oil industry using indigenous microorganism YL (Bacilllus sp YLB1, Trichoderma sp YLF8 and Yeast sp YLY3) can be seen in Figure 2.
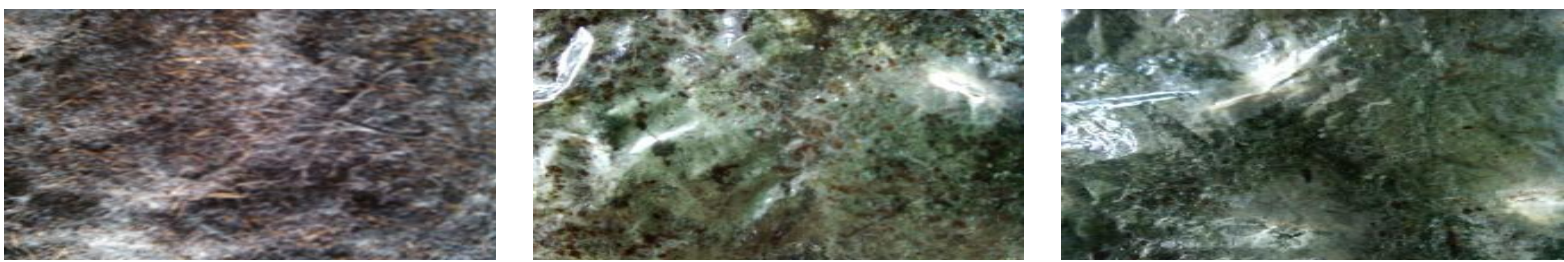

Fig 2. Formation of Mycelium In Substrates Based on Palm Waste (Yunilas et al., 2014)

\section{Effect of Treatment on NDF Content}

The results showed that combinations of different levels of fermented substrate with cocktail inoculums of indigenous microorganisms (MOIYL) could decrease the NDF content. Complete fermentation process using indigenous microbe "MOIYL" able to decrease NDF content caused by activity of indigenous microbial mix inoculum. Indigenous microbes produce multiple enzymes (endo$\beta$-1,4-glucanase, xylase, ananase and ligniperoksidase) and synergize in fiber degradation.

Table 1. NDF Content of Fermentation of Plantation Waste and Palm Oil Industry (\%)

\begin{tabular}{lccccc}
\hline \multicolumn{1}{c}{ Experiments } & M1 & M2 & M3 & M4 & Means \\
\hline S1 & $73.35^{\mathrm{A}}$ & $75.28^{\mathrm{A}}$ & $75.42^{\mathrm{A}}$ & $72.81^{\mathrm{A}}$ & 74.21 \\
S2 & $69.14^{\mathrm{B}}$ & $68.96^{\mathrm{B}}$ & $71.32^{\mathrm{B}}$ & $69.12^{\mathrm{B}}$ & 69.63 \\
S3 & $65.53^{\mathrm{C}}$ & $66.32^{\mathrm{C}}$ & $65.15^{\mathrm{C}}$ & $61.86^{\mathrm{C}}$ & 64.71 \\
\hline Means & 69.34 & 70.19 & 70.63 & 67.93 & \\
\hline
\end{tabular}

Note: Means with different superscripts in a column differ significantly. 
Test results of Duncan showed that NDF and ADF feed content with S3M4 treatment combination was significantly lower than other treatments (Table 1). This is due to the decreasing use of midrib and palm leaf as a source of forage indirect activities cause the microbe activity more optimal. Besides, the decrease of NDF content is also caused by positive synergy between bacteria, fungi and Yeast which keep increasing its activity. Synergistic microbes accelerate lignocellulosic bonding due to increased enzyme activity generated during the fermentation process. It appears that the enzyme activity of fiber degradation that indigenous microbial based on palm oil waste is able to loosen the lignocellulose bond so that the strong bond becomes unraveled.

The lowest NDF content of $61.86 \%$ indicates that the fermented substrate with mixed inoculum based on plantation waste and palm oil industry has good potential as animal feed ingredients. This is supported by the statement of Godoy and Elliot (1981) that the value of NDF can be used as a predictor of the digestibility of feed ingredients. The value of NDF is related to its digestibility, where the higher the NDF value the lower the digestibility (Fariani \& Akhadiarto, 2012) or conversely.

\section{Influence of Treatment on ADF Content}

The results showed that the combination of substrate and cocktail inoculums synergistically decreased the ADF content. S3 substrate interaction with indigenous microbes M4 resulted in lower ADF content is lower than other treatments (Table 2).

Table 2. Content of ADF Fermentation of Waste Plantation and Palm Oil Industry (\%)

\begin{tabular}{lccccc}
\hline Experiments & M1 & M2 & M3 & M4 & Means \\
\hline S1 & $62.50^{\mathrm{A}}$ & $62.02^{\mathrm{A}}$ & $59.86^{\mathrm{A}}$ & $61.38^{\mathrm{A}}$ & 61.44 \\
S2 & $57.53^{\mathrm{B}}$ & $56.44^{\mathrm{B}}$ & $57.90^{\mathrm{B}}$ & $57.70^{\mathrm{B}}$ & 57.39 \\
S3 & $53.18^{\mathrm{C}}$ & $51.72^{\mathrm{C}}$ & $52.12^{\mathrm{C}}$ & $48.49^{\mathrm{C}}$ & 51.38 \\
\hline Means & 57.74 & 56.73 & 56.63 & 55.86 & \\
\hline
\end{tabular}

Note: Means with different superscripts in a column differ significantly.

Factors affecting ADF values are cellulose and lignin because cellulose and lignin are part of the ADF. Low cellulose and lignin content followed by a low ADF content (Yunilas, 2016). The value of ADF is related to the energy content, where the higher the ADF value the lower the digestibility of the energy, and vice versa. The S3M4 feed has the lowest ADF value indicating that S3M4 has the potential to feed better than other treatments.

\section{Effect of Treatment on Lignin Contents}

The results of the diversity analysis showed that the treatment of the combination of various substrate levels had a very significant effect $(\mathrm{P}<0.01)$ on the lignin content (Table 3$)$. The content of lignin in treatment S3 is significantly lower than the treatment of S1 and S2. This illustrates that the combination of mixed indigenous microbial inoculums (Bacillus sp YLB1, Trichoderma sp YLF8 and Yeast sp YLY3) together more optimally reduce the lignin content of the S3 substrate compared to S1 and $\mathrm{S} 2$.

Table 3. Lignin Content Fermented Waste Plantation and Palm Oil Industry (\%)

\begin{tabular}{lccccc}
\hline Experiments & M1 & M2 & M3 & M4 & Means \\
\hline S1 & $16.05^{\mathrm{A}}$ & $16.96^{\mathrm{A}}$ & $16.77^{\mathrm{A}}$ & $16.19^{\mathrm{A}}$ & 16.49 \\
S2 & $15.99^{\mathrm{B}}$ & $15.80^{\mathrm{B}}$ & $15.20^{\mathrm{B}}$ & $15.15^{\mathrm{B}}$ & 15.54 \\
S3 & $10.52^{\mathrm{C}}$ & $10.47^{\mathrm{C}}$ & $10.21^{\mathrm{C}}$ & $10.09^{\mathrm{C}}$ & 10.32 \\
\hline Means & 14.19 & 14.41 & 14.06 & 13.81 & \\
\hline
\end{tabular}

S3M4 treatment of lignin content is lower than other treatments. Presumably this is because microbial inoculum (Bacillus sp YLB, Trichoderma sp YLF8 and Yeast sp YLF3) works more optimally in degrading fiber, resulting in a decrease in lignin content higher than other treatments 
The decrease in lignin levels by indigenous microbes showed that indigenous microbes (Bacillus sp YLB, Trichoderma sp YLF8 and Yeast sp YLF3) were able to synergize decresing lignin levels especially on S3 substrates. Wang (1984), states that during the process of bioconversing solid substrate progresses, the highest lignin degradation also occurs in the mycelium phase. In this phase one of the major constituents of lignin coniferyl alcohol is dehydrogenated by lacase or peroxidase enzyme. These peroxidase enzymes are involved in the delignification process and function to break the complex bonds of lignocellulose and lignohemiselulose into free compounds in mesomeric form.

During fermentation microbiological and biochemical changes are characterized by fluctuations in synergistic enzyme activity and microbes forming a succession pattern of growth, where there is mutual filling between indigenous microbes (Figure 4).

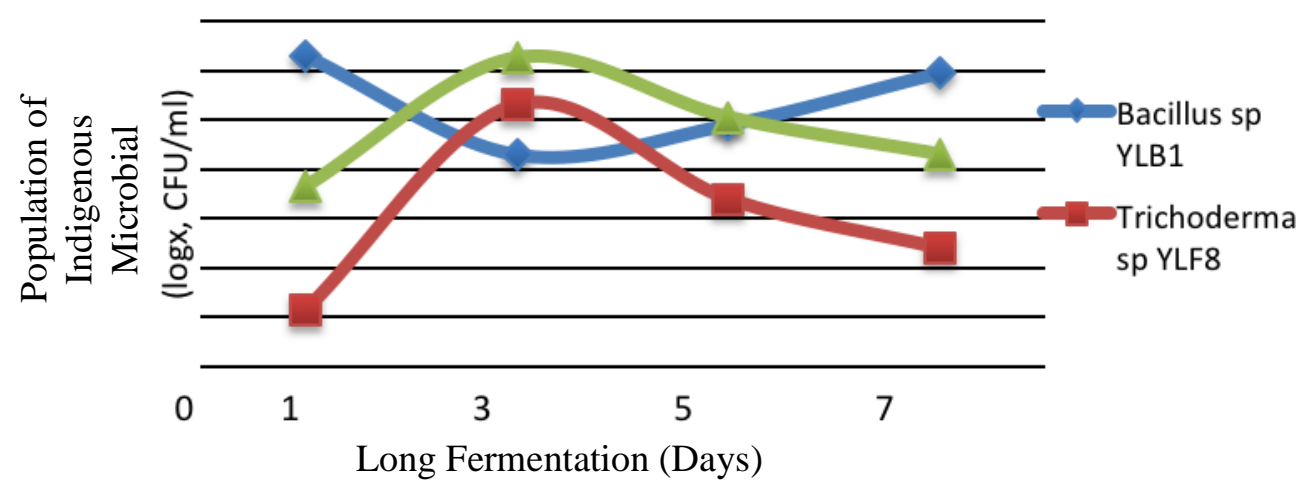

Fig 4. Indigenous Microbial Growth Patterns during Fermentation (Yunilas, 2016)

\section{CONCLUSION AND SUGGESTION}

Fermentation of palm oil waste (palm leaf cuts, lupur and palm kernel cake) using MOIYL probiotics can decrease the deterrent detergent fiber (NDF), Acid detergent fiber (ADF) and Lignin content so that MOIYL probiotics can be used as fermentation inoculum.

\section{REFERENCES}

Alam, M. Z., Machhur, M. A., \& Anwar M. N. (2004). Isolation, Purification, Characterization of Cellulolytic Enzymes Produced by Streptomyces amiyaensis. Journal Biology Science, 7(10), 1647-1653.

Batubara, L. P., Ginting, S. P., Simanihuruk, K., Sianipar, J., \& Tarigan, A. (2003). Pemanfaatan limbah Sawit dan Hasil Ikutan Perkebunan Kelapa Sawit sebagai Ransum Kambing Potong. Prosiding Seminar Teknologi Peternakan dan Veteriner, Bogor, 2930 September 2003.

Bayer, E. A., Morag, E, Lamed, R. (1994). The Cellulosome A Treasure-Trove for Biotechnology. TIBTECH 12, 379-386.

Beguin, P., \& Aubert, J. P. (1992). Cellulases. Encyclopedia of Microbiol, 1. Paris: Academic Press, Institut.

Brandt, Jr. R. T., \& Klopfenstein, T. J. (1986). Evaluation of alfalfa-corn cob associative action. I. Interactions between alfalfa hay an. ruminal escape protein on growth of lambs and steers. J. Anim. Sci. 63, 894-901. 
Dashtban, M., Schraft, H. \& Qin, W. (2009). Fungal Bioconversion of Lignocellulosic esidue: Opportunities and Perspectives. Int. J. Biol. Sci., 578-595.

Enari, T. M. (1983). Microbial Cellulase. in W. M. Fogarty (ed.). Microbial Enzymes and Biotechnology. New York: Applied Science Publisher.

Fariani, A., \& Akhadiarto, S. (2012). Pengaruh Lama Ensilase terhadap Kualitas Fraksi Serat Kasar Silase Limbah Pucuk Tebu (Saccharum Officinarum) yang Diinokulasi dengan Bakteri Asam Laktat Terseleksi. Jurnal Teknik. Lingkungan, 13(1). 85-92.

Fitriani, E. (2003). Aktivitas Enzim Karboksilmetil Selulase Bacillus pumilus Galur 55 pada Berbagai suhu Inkubasi. Skripsi. Bogor: Program Studi Kimia, Jurusan Kimia, Fakultas Matematika dan Ilmu Pengetahuan Alam, Institut Pertanian Bogor. (Unpublished).

Godoy, R. \& Elliot. R. (1981). Effect of tropical forages on rumen function and flow of nutrients to the proximal duodenum in cattle fed a molasses diet. Trop. Anim. Prod. 6, 159-166.

Goering, H. G., \& Van Soest, P.J. (1973). Forage Fiber Analysis (Apparatus Reagents, Procedure and Some Application). Agricultural Handbook, 379. ARS. USDA, Washington DC.

Hardjo, S., Indrasti, N. S., \& Bantacut, T. (1989). Biokonversi : Pemanfaatan Limbah Industri Pertanian. Pau-Pangan dan Gizi. Bogor: Institut Pertanian Bogor.

Holtzapple M. T. (1993). Cellulose. In: Encyclopedia of Food Science, Food Technology and Nutrition, 2: 2731-2738. Academic Press. London.

Immanuel, G., Bhagavath, C.M.A., Raj, P.I., Esakkiraj, P., \& Palavesam, A. (2007). Production and partial production of Cell in Coir Waste and Sawdust. Int of $J$ Microbiol. 3(1).

Krause D. O., Denman, S. E., Mackie, R. I., Morrison, M., Rae, A. L., Attwood, G. T., \& Mcsweeney, C. S. (2003). Opportunities To Improve Fiber Degradation In Rumen: Microbiology, Ecology And Genomics. Fems Microbiol. Rev. 27, 663-669.

Lehninger, A. L. (1993). Dasar-Dasar Biokimia. Erlangga, Jakarta.

Martina, A. et al. (2002). Optimasi Beberapa Faktor Fisik terhadap Laju Degradasi Selulosa Kayu Albasia dan Karboksimetilselulosa (CMC) secara Enzimatik oleh Jamur, FMIPA Universitas Riau, 2, 156-163.

Nelson \& Suparjo, (2011). Penentuan Lama Fermentasi Kulit Buah Kakao dengan Phanerochaete Chrysosporium: Evaluasi Kualitas Nutrisi secara Kimiawi. Agrinak, 1(1), 1-10.

Nicolini, L., Von H. C., \& Carilli, A. (1987). Solid State Fermentation Of Orange Peel and Grape Stalks By Pleurotus Ostreatus, Agrocybe Aegerita And Armillariella Mellea. Appl. Microbiology Biotechnology, 26, 95-98.

Ramin, M., Alimon, Ar., \& Ivan, M. (2010). Effect Fungal Treatment on The In Vitro Digestion of Palm Kernel Cake. Livest Res Rural Develop. 22. Www4.Agr.Gc.Ca/AafcAac/Display-Affic. (Diakses Pada 18 Januari 2011).

Steel, R. G., \& Torrie, H.J. (1995). Prinsip dan Prosedur Statistik. Suatu Pendekatan

Taherzadeh M. J. (1999). Ethanol From Lignocellulose: Physiological Effects of Inhibitors And Fermentation Strategies. Thesis. Göteborg: Department of Chemical Reaction Engineering, Chalmers University of Technology. (Unpublished). 
Van Soest, R. J. (1982). Nutritional Ecology of the Ruminant. USA: Durhom and Downey Inc.

Varga, G. A. \& Kovler, E. S. (1997). Microbial And Animal Limitation to Fiber Digestion and Utilization. J. Nutr., 127(5), 819-823.

Wajizah, S., Samadi., Yunasri, U., \& Elmy, M. (2015). Evaluasi Nilai Nutrisi dan Kecernaan In Vitro Pelepah Kelapa Sawit (Oil Palm Fronds) yang Difermentasi menggunakan Aspergillus niger dengan Penambahan Sumber Karbohidrat yang Berbeda. Agripet 15(1).

Wang, C. W. (1984). Cellulolytic Enzymes of Volvariella volvacea. In: Chang, S. T., and T. H. Quimio (Editors). Tropical Mushrooms. Biological Nature and Cultivation Methods. Hongkong: The Chinese University Press, 167-187.

Winarno, F. S. (1984). Enzim Pangan. Jakarta: PT. Gramedia.

Yunilas (2016). Aplikasi Bioteknologi dalam Pengolahan Pakan Komplit menggunakan Mikroba Indigenous Berbasis Limbah Perkebunan dan Industri Kelapa Sawit sebagai Pakan Ternak Ruminansia. Disertasi. Padang: Program Pascasarjana. Universitas Andalas. Padang. (Unpublished).

Yunilas., Lili, W., Yetti, M., \& Irsan, R. (2013). Potency of Indigenous Bacteria from Oil Palm Waste in Degrades Lignocellulose as A Sources of Inoculum Fermented to High Fibre Feed. Pakistan Journal of Nutrition, 12(9), 851-853.

Yunilas., Lili, W., Yetti, M., \& Irsan, R. (2014). Quality Improvement of Oil Palm WasteBased Feed Product through Indigenous Microbial Fermentation to Reach Sustainable Agriculture. International Journal on Advanced Science Engineering Information Technology, 4(4), 72-75. 